Table 4 Expression of viral p27 protein on BRdU-treated and normal CEF, JQEF and DEF

\begin{tabular}{|c|c|c|c|c|c|c|}
\hline \multirow[t]{2}{*}{ Cells } & \multicolumn{6}{|c|}{ Degree of fluorescence } \\
\hline & $100 \%+++$ & $50 \%+++$ & $100 \%++$ & $50 \% t+$ & $100 \%+$ & $50 \%+$ \\
\hline $\begin{array}{l}\text { CE-BL } \\
\text { CE-BL+BRdU } \\
\text { CE-C } \\
\text { CE-C + BRdU } \\
\text { JQEF } \\
\text { JQEF + BRdU } \\
\text { DEF } \\
\text { DEF+BRdU }\end{array}$ & $\begin{array}{l}20 \\
40 \\
20 \\
20 \\
20 \\
20 \\
20 \\
20\end{array}$ & $\begin{array}{r}20 \\
160 \\
20 \\
40 \\
20 \\
20 \\
20 \\
20\end{array}$ & $\begin{array}{r}40 \\
80 \\
20 \\
640 \\
20 \\
20 \\
20 \\
20\end{array}$ & $\begin{array}{r}80 \\
640 \\
20 \\
1280 \\
20 \\
20 \\
20 \\
20\end{array}$ & $\begin{array}{r}80 \\
1280 \\
40 \\
2560 \\
20 \\
20 \\
20 \\
20\end{array}$ & $\begin{array}{r}160 \\
2560 \\
80 \\
2560 \\
20 \\
20 \\
20 \\
20\end{array}$ \\
\hline
\end{tabular}

The figures are the reciprocal of the serum dilution giving the indicated degree of fluorescence in $100 \%$ or $50 \%$ of the cells. Cells were seeded sparsely on coverslips in Leighton tubes which were kept at $37^{\circ} \mathrm{C}$. One day later they were washed with phosphate-buffered saline, fixed with acetone for $10 \mathrm{~min}$, incubated for $45 \mathrm{~min}$ at $37{ }^{\circ} \mathrm{C}$ with increasing dilutions of the monospecific rabbit anti-p27 ASV immune serum and incubated for $30 \mathrm{~min}$ at room temperature with fluorescein conjugated globulin anti-rabbit $7 \mathrm{~S} \mathrm{IgG}$. +++ , Intense continuous fluorescence; ++ , intense granular fluorescence; + , moderate granular fluorescence. For details of cells see Table 2.

to the viral $s r c$ gene responsible for cell transformation ${ }^{16}$, the BRdU-induced TSSA could be the protein coded by the cellular src (sarc) gene. In this case, BRdU could induce the expression of the protein, which is normally repressed in untreated cells. The lack of reactivity of the anti-XC antiserum with BRdU-treated DEF could be due to the antigenic unrelatedness of the products of endogenous src of DEF and CEF. Experiments using specific antisera to BRdU-treated and untreated DEF are in progress to test this hypothesis. Second, the TSSA-related antigen(s) expressed on BRdU-treated CEF and JQEF could be unrelated to the antigenic determinant coded by the viral $s r c$ gene and related to another cellular determinant of ASVspecific TSSA. This determinant could be a cross-reacting antigen common to avian and mammalian cells and expressed after both BRdU treatment and virus-induced transformation-for instance, an early embryonal antigen. Because BRdU treatment also enhanced the expression of $p$ proteins in treated CEF, the mechanism of induction of the TSSA-related antigen might also be the same as that of induction of the cryptic chick helper factor.

We thank Dr P. Vigier for helpful suggestions and for critically reading the manuscript, and Mrs Y. Nouvian and Miss M. C. Chignol for technical assistance.

\section{JEAN-Michel BIQUARD}

Fondation Curie, Bâtiment 110,

Faculté des Sciences,

91405 - Orsay, France
12. Kurth, R., Bosch, V. \& Bolognesi, D. P. Virology 78, 511-521 (1977).

13. Lowy, D. R., Rowe, W. P., Teich, N. \& Harlley, J. W. Science 174, 155-156 (1971)

14. Robinson, H. L.. Swanson, C. A. \& Hruska, J. F. Virology 69, 63-74 (1976). 15. Sovova, V., Sainerova, H., Urbankova, M. \& Hlozanek, I. Int. J. Cancer 14, 259. 263 (1974)

16. Stehelin, D., Guntaka, R. V., Varmus, H. E. \& Bishop, J. M. J. molec. Biol. 101, 349-364 (i976).

17. Tereba, A., Skoog, L. \& Vogt, P. K. Virology 65, 524-534 (1975).

\section{Errata}

In the letter by R. S. Bradley and J. England, Nature 271, p. 736, the title should read: Influence of volcanic dust on glacier mass balance at high latitudes. In paragraph 4 , line 4, (TxMDD) should read ( $\left.\mathrm{T}_{\mathrm{x}} \mathrm{MDD}\right)$. In paragraph 5 the equations in lines 7 and 8 should read : $y=-2.79 x+224.8$ and $r=-0.94$. In line 26 for 1933-64 read 1963-64. In paragraph 7 , for $P<0.01$ read $P<0.001$. Figure 4 legend should include an extra line: Asterisks indicate data for $\leqslant 1$ month estimated.

In the letter 'Gating properties of acetylcholine receptor in newly formed neuromuscular synapses' by H. R. Brenner \& B. Sakmann Nature 271, p. 366, the time calibration bar in Fig. 2 should be marked $20 \mathrm{~ms}$, and that in Fig. 3 should read $2 \mathrm{~ms}$.

In the letter 'Regeneration of endoderm by ectoderm isolated from mouse blastocytes' by R. Pederson, Nature 270, 435, in paragraph 2 line 3 for 'thin inner cell masses' read 'then inner cell masses'.

\title{
Michele Aupoix
}

\author{
Unité de Virologie Fondamentale et Appliquée \\ INSERM U 51, \\ Groupe de Recherche 33 CNRS, \\ 1, Place Professeur Joseph Renaut, \\ 69371 - Lyon CEDEX 2, France
}

\section{Nature Index and Binders}

The complete Index for 1976 is available, price $£ 2.50$ (UK), US\$5.00 (Rest of World). Copies of the 1975 index are still on sale, price $£ 2.25$ (UK), US\$5.00 (Rest of World).

Binders for the journal are also available at $£ 8.00$ (UK). US\$16.00 (Rest of World) for three: a year of Nature fits into three binders.

All prices include postage. Payment may be made in any currency at the prevailing exchange rate. Orders should be sent, accompanied by remittance, to Macmillan Journals Ltd, Brunei Road, Basingstoke, Hampshire, RG21 2XS. England. 